\title{
Kajian Substitusi Transportasi Online pada Perjalanan Menuju Simpul Transportasi di Kota Bandung
}

\author{
MUHAMAD RIZKI, ALIA MAEMUNANNISA, OKA PURWANTI \\ Program Studi Teknik Sipil, Institut Teknologi Nasional Bandung, Indonesia \\ Email: Muhamadrizki1404@itenas.ac.id
}

\begin{abstract}
ABSTRAK
Penelitian sebelumnya menemukan bahwa transportasi online menggantikan kebutuhan angkutan umum dan pribadi. Namun penelitian sebelumnya umumnya berfokus pada perjalanan sehari-hari, sedangkan investigasi pengaruh substitusi transportasi online pada perjalanan menuju simpul transportasi masih terbatas. Penelitian ini bertujuan untuk melakukan eksplokrasi pengaruh substitusi pengguna transportasi online pada perjalanan menuju simpul transportasi di Kota Bandung. Model diskriminan digunakan pada data yang dikumpulkan dengan penyebaran kuesioner secara online kepada pengguna transportasi online. Deksripsi data menunjukkan terdapat tiga moda yang digunakan untuk perjalanan menuju simpul sebelum adanya moda transportasi online yaitu kendaraan pribadi, angkutan kota, dan bus/shuttle bus. Analisis juga menemukan bahwa saat ini jika angkutan online berhenti beroperasi, pengguna angkutan umum sebelumnya akan berpindah kepada angkutan pribadi. Substitusi dari angkutan umum ditemukan terjadi pada simpul transportasi udara.
\end{abstract}

Kata kunci: substitusi, angkutan online, analisis diskriminan

\begin{abstract}
Previous research has found that the rise of online transportation replaces the need for public and private transportation. However, previous research has generally focused on daily commuting, whereas investigations on the effect of online transportation substitution on transport station trips are still limited. This study aims to explore the substitution effect of online transport in transport stations trips in Bandung City. The discriminant model is used in the data collected by distributing questionnaires online to online transportation users. The decriptive analysis show that there are three modes used to travel to the node before the existence of online transportation modes, namely private vehicles, paratransit (angkot), and buses/shuttle. The analysis also found that currently if online transportation stops operating, previous public transport users will switch to private transportation. The substitution of public transport is found to occur at air transportation nodes.
\end{abstract}

Keywords: substitution, online transportation, discriminant analysis 


\section{PENDAHULUAN}

Globalisasi dan modernisasi kehidupan telah melahirkan berbagai penemuan yang memudahkan aktivitas masyarakat, salah satunya adanya teknologi informasi pada angkutan umum yang berbasis online [1]. Jenis transportasi ini memberikan kemudahan untuk memesan jasa transportasi umum yang diinginkan para pengguna jasa lewat aplikasi di smartphone. Angkutan umum online memiliki pengaruh substitusi baik pada angkutan pribadi maupun angkutan umum di berbagai perkotaan di dunia [2].

Penggunaan angkutan online telah melahirkan pro dan kontra di tengah masyarakat dan mengakibatkan berubahnya pengguna angkutan umum maupun pribadi [3]. Hal ini menarik berbagai peneliti dari beragam disiplin untuk menginvestigasi pengaruh angkutan online terhadap penggunaan angkutan umum dan angkutan pribadi [4], [5] serta dampaknya terhadap lingkungan [6]. Mayoritas studi menginvestigasi aspek pemilihan moda dari penggunaan angkutan online memiliki temuan beragam. Seperti studi dari Clewlow \& Mishra [4] yang menemukan bahwa angkutan online menurukan penggunaan kereta ringan dan bus di berbagai kota-kota di Amerika Serikat. Di sisi lain, beberapa studi di Indonesia oleh Irawan et al. [5] menemukan bahwa pengguna angkutan online juga merupakan pengguna angkutan massal rel seperti Kereta Rel Listrik (KRL) ataupun Moda Raya Terpadu (MRT) di DKI Jakarta. Variasi temuan ini menyatakan bahwa penting melakukan investigasi secara spesifik di Kota Bandung dalam rangka merumuskan kebijakan untuk manajemen angkutan online.

Penurunan penggunaan angkutan umum yang diakibatkan oleh angkutan online tidak hanya terjadi untuk perjalanan rutin. Perjalanan menuju simpul transportasi juga mengalami hal seragam. Seperti pengguna bus dan taksi bandara Soekarno Hatta yang berkurang akibat adanya transportasi online [7] Alhasil, beberapa terminal dan bandara melakukan pelarangan operasi angkutan online [8]. Perjalanan menuju simpul transportasi merupakan salah satu perjalanan penting untuk fasilitasi kegiatan pekerjaan, sosial, maupun kebudayaan pada lokasi dengan jarak spasial yang lebih tinggi. Disisi lain, mayoritas studi tentang pemilihan moda angkutan online berfokus pada perjalanan rutin [4], [5], sedangkan studi terhadap perjalanan menuju simpul transportasi belum banyak dilakukan. Studi tentang penggunaan angkutan online yang mengakomodasi perjalanan ke simpul transportasi sangat penting dengan kuantitasnya yang cukup besar berkontribusi kepada kemacetan khususnya di lokasi simpul.

Berdasarkan latar belakang tersebut, studi ini mencoba untuk memahami efek substitusi transportasi online pada perjalanan menuju simpul transportasi. Untuk mencapai tujuan tersebut, analisis dilakukan pada data yang dikumpulkan dari penyebaran secara online kepada pengguna angkutan online di Kota Bandung. Kuesioner dibentuk berdasarkan hasil studi literatur terkait dengan perilaku pengguna angkutan online. Analisis dilakukan terhadap faktor karakteristik pengguna dan perjalanan serta alasan penggunaan angkutan online.

Makalah ini terdiri dari beberapa bagian. Pada bagian kedua, literatur sebelumnya tentang angkutan online akan dideskripsikan dilanjutkan dengan penjelasan tentang metodologi penelitian. Analisis dan diskusi akan dideskripsikan pada bagian ke empat dan makalah ditutup dengan dilakukan penyimpulan dari hasil penelitian.

\section{TRANSPORTASI ONLINE DI INDONESIA}

Transportasi online merupakan inovasi layanan trasportasi di mana pengguna dapat memesan perjalanannya melalui aplikasi yang disediakan oleh penyedia jasa, setelah itu pengemudi dapat merespon pesanan melalui aplikasi tersebut [9]. Platform angkutan online menghubungkan pengguna dan kelompok pengemudi dengan menampilkan informasi 
mengenai kendaraan (pelat nomor dan jenis kendaraan), biaya, dan waktu tempuh. Transportasi online memberikan beberapa manfaat seperti pengguna jasa dan pengemudi transportasi online dapat mengetahui lokasi satu sama lain secara akurat, pengguna jasa dapat melihat informasi pengemudi dan kendaraannya, serta pengguna dapat lebih mudah mengakses kendaraan untuk bepergian ke tempat lain sehingga waktu yang digunakan lebih efektif [5].

Transportasi angkutan umum berbasis online ini menjadi hal yang baru di Indonesia, sejak pertama kali munculnya angkutan umum online ini semakin hari semakin bertambahnya para pengguna sarana transportasi tersebut. Perkembangan angkutan online di Indonesia pun hadir di awal tahun 2015, dengan bertambahnya tingkat keinginan konsumen dalam membutuhkan transportasi yang mudah maka perusahaan pertama yang hadir di Indonesia adalah Go-Jek dengan menawarkan moda transportasi kendaraan bermotor. Beberapa bulan setelahnya perusahaan yang lain seperti GRAB dan UBER pun hadir di Indonesia, dengan penawaran moda transportasi yang sama yaitu kendaraan bermotor. Dengan berkembangnya teknologi yang semakin canggih maka hadir juga angkutan online beroda empat yang semakin menjadikan salah satu alternatif masyarakat di Indonesia untuk memilih moda transportasi. Terdapat beberapa jenis angkutan umum berbasis online, yaitu angkutan sepeda motor dan angkutan mobil. Angkutan sepeda motor berbasis online disebut ojek yang merupakan sarana angkutan umum bermotor roda dua yang disediakan untuk digunakan oleh umum dengan memberikan sejumlah biaya atau ongkos tertentu sebagai bayaran terhadap layanan jasanya atas dasar kesepakatan bersama [10]. Angkutan mobil berbasis online atau biasa disebut taksi online, yaitu angkutan dengan menggunakan angkutan umum yang diberi tanda khusus dan dilengkapi dengan argometer yang melayani angkutan dari pintu ke pintu dalam wilayah operasi yang terbatas (Keputusan Menteri Perhubungan Nomor 35 Tahun 2003).

Adapun perkembangan jumlah pengguna angkutan online menunjukkan bahwa pelayanannya sangat diminati [11]. Dengan banyaknya pengguna, para peneliti tertarik menginvestigasi faktor pemilihan angkutan online untuk perjalanan [1], [4], [5], [12]-[14]. Berbagai penelitian telah menginvestigasi karakteristik penggunaan angkutan online. Angkutan online memiliki pengaruh subsitusi dan komplementer [15]. Substitusi merupakan pengaruh yang mengantikan moda angkutan yang ada, komplementer merupakan pengaruh yang menjadi pendukung moda angkutan yang ada saat sekarang. Berbagai penelitian berfokus pada fungsi substitusi karena diharapkan angkutan online menggantikan ketergantungan kepada kendaraan pribadi dan tidak mengsubstitusi angkutan umum. Review studi angkutan online dari Tirachini [2] menyebutkan bahwa substitusi terjadi baik pada angkutan pribadi dan angkutan umum di berbagai perkotaan di dunia. Adapun penelitian seperti Irawan, et al. [5] menujukkan bahwa terdapat pengaruh positif angkutan online kepada penggunaan angkutan umum. Temuan ini menandakan pengaruh subsitusi perlu didalami berdasarkan karakteristik pengguna angkutan online.

\section{METODOLOGI}

\subsection{Analisis Diskriminan}

Analisis diskriminan adalah bagian dari analisis statistik perubah ganda (multivariate statistical analysis) yang bertujuan untuk memisahkan beberapa kelompok data yang sudah terkelompokkan dengan cara membentuk fungsi diskriminan [16]. Analisis diskriminan dalam penelitian ini digunakan untuk membedakan karakteristik pengguna angkutan umum berbasis online berdasarkan moda yang digunakan sebelum adanya transportasi online. Dalam hal ini, pembentukan fungsi diskriminan dilakukan dengan menggunakan metode step-wise dimana variabel independen dimasukkan satu persatu ke dalam model diskriminan [16]. Pada proses 
ini akan terdapat variabel yang tetap ada dalam model dan ada variabel yang dihilangkan dari model.

Model umum analisis diskriminan merupakan suatu kombinasi linear yang bentuknya memenuhi Persamaan 1 berikut:

$$
Z=a+b_{1} X_{1}+b_{2} X_{2}+\ldots+b_{n} X_{n}
$$

keterangan:

$\begin{array}{ll}Z & =\text { nilai diskriminan, } \\ b_{1} \ldots b_{n} & =\text { nilai koefisien, } \\ \text { a } & =\text { konstanta, } \\ X_{1} \ldots X_{n} & =\text { variabel bebas. }\end{array}$

\subsection{Pengumpulan Data}

Pengumpulan data dilakukan untuk mencatat perilaku penggunaan transportasi online dan transportasi yang sebelumnya responden gunakan untuk menuju simpul transportasi. Untuk menyelidiki faktor-faktor yang mempengaruhi efek substitusi transportasi online, studi ini menggabungkan pengaruh karakteristik sosio-demografis dan perjalanan individu, penggunaan Setelah serangkaian tinjauan pustaka terkait perilaku perjalanan transportasi online [1], [5], [10], kuesioner yang terdiri dari tiga bagian pun dibentuk.

Pada bagian pertama responden ditanyai tentang karakterisik sosio-demografi responden seperti usia, jenis kelamin, pendapatan, dan pekerjaan. Selanjutnya, diberikan pertanyaan tentang karakteristik perjalanan responden seperti jarak, durasi, dan biaya perjalanan. Selain itu karakteristik perjalanan seperti jumlah saudara/kerabat/rekan yang berpergian bersama dan jumlah barang bawaan (tas/koper). Pada bagian terakhir ditanyakan moda yang digunakan untuk menuju simpul transportasi saat transportasi online belum ada serta alternatif jika saat ini transportasi online tiba-tiba tidak ada.

Data dikumpulkan saat pandemi COVID-19 terjadi di Indonesia [17]. Dengan resiko penularan dengan kontak fisik, pengumpulan data direncanakan dengan penyebaran secara online. Dalam rangka penyebaran secara online, kuesioner fisik diubah dalam format online. Menggunakan platform formulir Google, kuesioner online dikembangkan. Formulir kuesioner online diubah menjadi web-link dan didistribusikan melalui berbagai platform media sosial (Facebook, Instagram, Twitter, Line, dan WhatsApp) sehingga dapat menghindari interaksi tatap muka selama survei. Rekrutmen responden menggunakan metode convenience sampling, dan dengan penyebaran secara online tersebut diatas pada relasi para peneliti dan dibantu dengan para mahasiswa dari universitas para peneliti. Survei dilakukan sejak Mei hingga Juni 2020. Dari periode survei tersebut, setelah melakukan review data, 163 data pengguna transportasi online di Kota Bandung didapatkan untuk dianalisis.

\subsection{Deskripsi Responden}

Deskripsi dari responden disajikan pada Tabel 1. Berdasarkan karakteristik substitusi; sebanyak 38,04\% responden menggunakan kendaraan pribadi; $14,72 \%$ responden menggunakan angkutan kota (angkot) dan 47,24\% responden menggunakan bus (damri) sebagai moda transportasi menuju simpul transportasi sebelum adanya transportasi online (moda asal/sebelumnya). Responden didominasi oleh responden yang berjenis kelamin wanita $(58,9 \%)$, dengan pekerjaan sebagai mahasiswa $(67,7 \%)$. 
Tabel 1. Deskripsi Responden

\begin{tabular}{|c|c|c|c|c|}
\hline \multicolumn{2}{|c|}{ Variabel } & \multicolumn{2}{|c|}{$\begin{array}{lc} & \text { Proporsi [\%] } \\
\text { Pribadi } & \text { Angkutan Kota } \\
2 & \mathrm{~N}=24 \\
& 14,70 \% \\
\end{array}$} & $\begin{array}{c}\text { Bus/ Shuttle } \\
\mathrm{N}=77 \\
47,3 \%\end{array}$ \\
\hline \multirow{6}{*}{ Jenis Kelamin } & Pria & 40,3 & 50,0 & 39,0 \\
\hline & Wanita & 59,7 & 50,0 & 61,0 \\
\hline & Mahasiswa/Pelajar & 67,7 & 62,5 & 64,9 \\
\hline & Wiraswasta & 12,9 & 8,3 & 5,2 \\
\hline & Pegawai Negeri/TNI/Polri & 1,6 & 0,0 & 0,0 \\
\hline & Pegawai Swasta/BUMN & 6,5 & 12,5 & 22,1 \\
\hline \multirow[t]{7}{*}{ Pekerjaan } & Dosen/Guru/Dokter & 4,8 & 16,7 & 3,9 \\
\hline & Ibu Rumah Tangga & 4,8 & 0,0 & 1,3 \\
\hline & Lainnya & 1,6 & 0,0 & 1,3 \\
\hline & Tidak Bekerja & 0,0 & 0,0 & 1,3 \\
\hline & $<$ Rp.1 juta & 22,6 & 12,5 & 45,5 \\
\hline & Rp.1 juta -Rp.2 juta & 9,7 & 20,8 & 10,4 \\
\hline & Rp.2 juta - Rp.4 juta & 21,0 & 29,2 & 14,3 \\
\hline Pendapatan/ uang & Rp.4 juta -Rp.6 juta & 19,4 & 16,7 & 18,2 \\
\hline \multirow[t]{4}{*}{ saku per bulan } & Rp.6 juta -Rp.8 juta & 9,7 & 4,2 & 9,1 \\
\hline & Rp. 8 juta -Rp.10 juta & 0,0 & 4,2 & 1,3 \\
\hline & Rp.10 juta -Rp.12 juta & 3,2 & 4,2 & 1,3 \\
\hline & $>$ Rp.12 juta & 14,5 & 8,3 & 0,0 \\
\hline Moda Transportasi & Sepeda Motor & 33,9 & 75,0 & 7,8 \\
\hline Online & Mobil & 66,1 & 25,0 & 92,2 \\
\hline \multirow{3}{*}{$\begin{array}{l}\text { Moda Angkutan di } \\
\text { Simpul }\end{array}$} & Pesawat & 53,2 & 12,5 & 58,4 \\
\hline & Kereta Api & 33,9 & 58,3 & 37,7 \\
\hline & Bus AntarKota & 12,9 & 29,2 & 3,9 \\
\hline \multirow{4}{*}{$\begin{array}{l}\text { Kelas Moda yang } \\
\text { Digunakan }\end{array}$} & Ekonomi & 69,4 & 66,7 & 89,6 \\
\hline & Busnis & 19,4 & 25,0 & 9,1 \\
\hline & Eksekutif & 11,3 & 8,3 & 1,3 \\
\hline & 1 & 25,8 & 20,8 & 54,5 \\
\hline Jumlah Orang yang & $2-3$ & 30,6 & 58,3 & 24,7 \\
\hline \multirow{3}{*}{ Ikut Dalam Perjalanan } & 4- 5 & 24,2 & 12,5 & 9,1 \\
\hline & $>5$ & 19,4 & 8,3 & 11,7 \\
\hline & 1 & 43,5 & 29,2 & 62,3 \\
\hline \multirow{5}{*}{$\begin{array}{l}\text { Jumalah Koper yang } \\
\text { Dibawa }\end{array}$} & $2-3$ & 25,8 & 20,8 & 14,3 \\
\hline & 4- 5 & 3,2 & 0,0 & 1,3 \\
\hline & $>5$ & 1,6 & 0,0 & 0,0 \\
\hline & Tidak Membawa & 25,8 & 50,0 & 22,1 \\
\hline & $<2 \mathrm{~km}$ & 3,2 & 25,0 & 1,3 \\
\hline \multirow{5}{*}{$\begin{array}{l}\text { Rata-Rata Jarak } \\
\text { Rumah Menuju Simpul } \\
\text { Transportasi }\end{array}$} & $2-4 \mathrm{~km}$ & 11,3 & 20,8 & 6,5 \\
\hline & $4-6 \mathrm{~km}$ & 14,5 & 12,5 & 7,8 \\
\hline & $6-8 \mathrm{~km}$ & 14,5 & 16,7 & 15,6 \\
\hline & $8-10 \mathrm{~km}$ & 14,5 & 12,5 & 15,6 \\
\hline & $>10 \mathrm{~km}$ & 41,9 & 12,5 & 53,2 \\
\hline \multirow{6}{*}{$\begin{array}{l}\text { Rata-Rata Waktu } \\
\text { Tempuh Rumah } \\
\text { Menuju Simpul } \\
\text { Transportasi }\end{array}$} & $<15$ menit & 4,8 & 25,0 & 2,6 \\
\hline & 15-30 menit & 40,3 & 37,5 & 19,5 \\
\hline & $31-60$ menit & 33,9 & 29,2 & 20,8 \\
\hline & $61-90$ menit & 8,1 & 4,2 & 22,1 \\
\hline & $>90$ menit & 12,9 & 4,2 & 35,1 \\
\hline & < Rp.10.000 & 4,8 & 16,7 & 2,6 \\
\hline Rata-Rata Biaya & Rp.10.001-Rp.20.000 & 8,1 & 29,2 & 3,9 \\
\hline Perjalanan Dari & Rp.20.001-Rp.30.000 & 24,2 & 20,8 & 1,3 \\
\hline Rumah Menuju Simpul & Rp.30.001-Rp.40.000 & 12,9 & 8,3 & 15,6 \\
\hline \multirow{2}{*}{ Transportasi } & Rp.40.001-Rp.50.000 & 21,0 & 4,2 & 20,8 \\
\hline & $>$ Rp. 50.000 & 29,0 & 20,8 & 55,8 \\
\hline \multirow{5}{*}{$\begin{array}{l}\text { Alternatif Moda yang } \\
\text { Digunakan Jika Tidak } \\
\text { Mendapatkan } \\
\text { Transportasi Online }\end{array}$} & Kendaraan Pribadi & 53,2 & 25,0 & 5,2 \\
\hline & Angkot & 6,5 & 45,8 & 1,3 \\
\hline & Bus & 30,6 & 12,5 & 90,9 \\
\hline & Taksi & 8,1 & 16,7 & 2,6 \\
\hline & Ojek & 1,6 & 0,0 & 0,0 \\
\hline
\end{tabular}

Mayoritas memiliki pendapatan per bulan kurang dari Rp.1.000.000 (31,9\%) dan menggunakan transportasi online mobil (72,4\%). Sebagian besar responden menuju bandara $(49,7 \%)$. Kelas moda yang dipilih responden adalah kelas ekonomi $(78,5 \%)$ dan jumlah penumpang hanya satu orang $(38,7 \%)$. Mayoritas responden membawa satu buah tas $(65 \%)$ dan satu buah koper $(50,3 \%)$. Mayoritas responden memiliki rata-rata jarak rumah menuju 
simpul trasnportasi dengan menggunakan trasnportasi online yaitu lebih dari $10 \mathrm{~km} \mathrm{(42,9 \% ).}$ Rata-rata waktu tempuh responden menuju simpul transportasi adalah 15 menit sampai 30 menit (30,1\%). Rata-rata biaya perjalanan menggunakan transportasi online adalah lebih dari Rp 50.000 (40,5\%). Jika tidak tersedianya transportasi online maka alternatif moda yang dipilih oleh responden adalah bus $(56,4 \%)$.

\section{ANALISIS}

Analisis diskriminan merupakan teknik statistika yang dipergunakan untuk mengklasifikasikan suatu individu atau observasi ke dalam suatu kelas atau kelompok berdasarkan sekumpulan variabel-variabel. Dalam penelitian ini terdapat variabel bebas yaitu karakteristik pengguna (X) dan variabel terikat yaitu moda asal $(\mathrm{Y})$. Analisis menggunakan metode stepwise dengan cara memasukkan seluruh variabel bebas ke dalam persamaan diskriminan berdasarkan kekuatan pembeda dan dikeluaran satu per satu dengan mengevaluasi kualitas model [16]. Pada proses ini terdapat beberapa variabel yang tetap digunakan pada model analisis ini dan ada kemungkinan satu atau lebih variabel bebas yang dibuang dari model karena tidak digunakan dalam model diskriminan ini. Pada penelitian ini, moda asal dibagi jadi 3 kelompok yaitu kendaraan pribadi, angkutan umum, bus, sehingga dihasilkan 2 fungsi diskriminan yang memisahkan kelompok tersebut. Variabel bebas diubah menjadi variabel dummy.

Kualitas model disajikan pada bagian bawah Tabel 1. Diketahui nilai korelasi kanonikal untuk masing-masing fungsi adalah sebagai berikut. Fungsi 1 sebesar sebesar 0,770; maka dapat disimpulkan bahwa 59,2\% varians variabel moda yang digunakan sebelumnya dapat dijelaskan oleh variabel bebas melalui persamaan diskriminan. Sedangkan fungsi 2 sebesar 0,536; sehingga $28,7 \%$ varians variabel moda yang digunakan sebelumnya dapat dijelaskan oleh variabel bebas melalui persamaan diskriminan. Berdasarkan uji wilks lamda antar fungsi, ditemukan bahwa fungsi diskriminan dapat mengelompokkan / membedakan responden yang sebelumnya menggunakan Kendaraan pribadi, angkutan kota, dan bus. Hal ini dikarenakan nilai signifikansi lebih kecil dari 5\%. Secara keseluruhan, hasil keseluruhan model diskriminan sudah menklasifikasikan $74,2 \%$ responden dengan benar. Sebelum melakukan interpretasi model, dilakukan pembacaan fungsi pusat grup (FPG). Hasil model menujukkan bahwa fungsi 1 memisahkan responden yang sebelumnya menggunakan angkutan kota $(1,855)$ dengan yang menggunakan bus/shuttle $(-1,207)$. Fungsi 2 memisahkan responden yang sebelumnya menggunakan kendaraan pribadi $(0,690)$ dengan yang menggunakan angkutan kota $(-1,158)$.

Fungsi pertama memisahkan responden yang sebelumnya menggunakan angkutan kota dengan responden yang sebelumnya menggunakan bus/shuttle. Hasil model menunjukkan bahwa pengguna angkutan online yang memilih alternatif bus/shuttle cenderung menggunakan angkutan umum. Pengguna angkutan online yang membawa tas sebanyak satu buah cenderung menggunakan angkutan kota sebelumnya. Responden yang menggunakan alternatif kendaraan pribadi cenderung lebih menggunakan bus/shuttle sebelumnya.

Fungsi kedua memisahkan responden yang sebelumnya menggunakan kendaraan pribadi dengan responden yang sebelumnya menggunakan angkutan umum. Hasil model diskriminan menunjukkan bahwa pengguna yang memilih alternatif angkutan kota cenderung menggunakan kendaraan pribadi sebelumnya. Pengguna angkutan online yang memilih alternatif kendaraan pribadi pada perjalanan simpul menuju bandara, cenderung pengguna angkutan kota sebelumnya. Dalam aspek karakteristik perjalanan, pengguna yang memilih alternatif kendaraan mobil saat tidak mendapatkan pelayanan transportasi online saat ini cenderung pengguna angkutan kota sebelum adanya transportasi online. 


\section{KESIMPULAN}

Penelitian ini berfokus kepada karakteristik pengguna angkutan online yang melakukan substitusi menuju simpul transportasi yang ada di Kota Bandung (Tabel 2), dengan melihat moda transportasi apa yang digunakan sebelum adanya transportasi online. Moda transportasi yang dimaksud adalah kendaraan pribadi, angkutan umum, dan bus. Kendaraan pribadi yang dimaksud seperti sepeda motor, mobil, serta sepeda. Menurut Irawan et al. [5] dan Rizki et al. [1] penggunaan transportasi online berdampak terhadap penggunaan transportasi pribadi, bahwa terjadi peralihan dari kendaraan pribadi ke transportasi online.

Tabel 2. Model Diskriminan Substitusi Transportasi Online pada Perjalanan Menuju Simpul Transportasi

\begin{tabular}{|c|c|c|c|c|c|c|c|}
\hline \multirow{2}{*}{ No } & \multirow{2}{*}{\multicolumn{2}{|c|}{ Variabel }} & \multicolumn{3}{|c|}{ Equality of Group Means } & \multicolumn{2}{|c|}{$\begin{array}{l}\text { Matrix } \\
\text { Struktur }\end{array}$} \\
\hline & & & $\begin{array}{l}\text { Wilks' } \\
\text { Lambda }\end{array}$ & $\mathbf{F}$ & Sig. & $\mathbf{F 1}$ & $\mathbf{F 2}$ \\
\hline 1 & \multicolumn{2}{|l|}{ Usia diantara 19-25 tahun [D] } & 0,886 & $\begin{array}{c}102,61 \\
0\end{array}$ & 0,000 & 0,296 & 0,045 \\
\hline 2 & \multicolumn{2}{|l|}{ Pendapatan < 1jt ${ }^{[D]}$} & 0,919 & 7,019 & 0,001 & 0,245 & 0,022 \\
\hline 3 & \multicolumn{2}{|c|}{ Transportasi online (mobil) menuju simpul[D] } & 0,734 & 28,954 & 0,000 & 0,473 & $-0,301$ \\
\hline 4 & \multicolumn{2}{|l|}{ Moda angkutan pesawat ${ }^{[D]}$} & 0,902 & 8,676 & 0,000 & 0,206 & $-0,340$ \\
\hline 5 & \multicolumn{2}{|l|}{ Kelas Ekonomi $[\mathrm{D}]$} & 0,934 & 5,623 & 0,004 & 0,215 & 0,088 \\
\hline 6 & \multicolumn{2}{|l|}{ Jumlah penumpang 1 org ${ }^{[D]}$} & 0,903 & 8,545 & 0,000 & 0,266 & 0,097 \\
\hline 7 & \multicolumn{2}{|l|}{ Jumlah penumpang 2-3 org ${ }^{[D]}$} & 0,941 & 5,014 & 0,008 & $-0,168$ & 0,231 \\
\hline 8 & \multicolumn{2}{|l|}{ Membawa tas 1 buah [D] } & 0,849 & 14,250 & 0,000 & 0,346 & 0,099 \\
\hline 9 & \multicolumn{2}{|l|}{ Membawa koper 1 buah [D] } & 0,939 & 5,163 & 0,007 & 0,210 & $-0,037$ \\
\hline 10 & \multicolumn{2}{|l|}{ Jarak > $10 \mathrm{~km}{ }^{[\mathrm{D}]}$} & 0,924 & 6,610 & 0,002 & 0,211 & $-0,209$ \\
\hline 11 & \multicolumn{2}{|c|}{ Waktu > 90 menit (menggunakan transportasi online) ${ }^{[D]}$} & 0,908 & 8,140 & 0,000 & 0,264 & 0,035 \\
\hline 12 & \multicolumn{2}{|c|}{ Biaya $>50$ rb (menggunakan transportasi online) ${ }^{[D]}$} & 0,909 & 7,965 & 0,001 & 0,260 & 0,057 \\
\hline 13 & \multicolumn{2}{|c|}{ Alternatif memilih kendaraan pribadi $[\mathrm{D}]$} & 0,750 & 26,732 & 0,000 & $-0,358$ & $-0,605$ \\
\hline 14 & \multicolumn{2}{|l|}{ Alternatif memilih angkot ${ }^{[D]}$} & 0,741 & 28,012 & 0,000 & $-0,317$ & 0,609 \\
\hline 15 & \multicolumn{2}{|l|}{ Alternatif memilih Bus $e^{[\mathrm{D}]}$} & 0,553 & 64,631 & 0,000 & 0,740 & 0,166 \\
\hline \multicolumn{2}{|c|}{$\begin{array}{l}\text { Eigen Values F1;F2 [Canonical } \\
\text { Correlation] }\end{array}$} & 1,$454 ; 0,404[0,770 ; 0,536]$ & & \multirow{3}{*}{ FPG } & $\begin{array}{l}\text { Moda } \\
\text { Asal }\end{array}$ & $\mathrm{F} 1$ & $\mathrm{~F} 2$ \\
\hline \multicolumn{2}{|c|}{ Wilks' Lambda F1-F2; F2 [p-value] } & 0,$29 ; 0,712[0,000 ; 0,000]$ & & & $\mathrm{KP}$ & 0,622 & 0,690 \\
\hline \multicolumn{2}{|c|}{ Percent Correct (\%) } & 74,2 & & & AK & 1,855 & $-1,158$ \\
\hline \multicolumn{3}{|c|}{$\begin{array}{l}\text { FPG = Fungsi pusat grup; }[\mathrm{D}]=\text { variabel } d u m m y ~ 1=\text { ya, } 0 \text { lainnya; } \\
\mathrm{KP}=\text { Kendaraan Pribadi; } \mathrm{AK}=\text { Angkot; } \mathrm{BS}=\mathrm{Bus} / \text { shuttle }\end{array}$} & & & BS & $-1,207$ & $-0,211$ \\
\hline
\end{tabular}

Berdasarkan hasil proporsi responden, sebanyak $65,6 \%$ pengguna transportasi online adalah mahasiswa yang melakukan perjalanan menuju simpul transportasi, hal ini menegaskan penelitian sebelumnya bahwa mayoritas pengguna transportasi online adalah pengguna berusia muda [4]. Hasil penelitian juga menunjukkan efek substitusi bus (56,4\%) dan kendaraan pribadi $(26,4 \%)$ akibat adanya transportasi online. Hal ini menegaskan bahwa adanya persamaan dengan penelitian Tirachini [2] yang menyebutkan bahwa susbtitusi terjadi baik pada angkutan pribadi dan angkutan umum di berbagai perkotaan di dunia.

Dari hasil penelitian menunjukkan bahwa orang yang melakukan perjalanan menuju simpul bandara adalah yang sebelumnya menggunakan angkutan umum sebelum adanya transportasi online, namun setelah adanya transportasi online masyarakat beralih 
menggunakannya, maka menunjukkan bahwa terjadi substitusi moda transportasi dari yang menggunakan angkutan umum menjadi angkutan online dalam perjalanan menuju bandara.

Penelitian juga menunjukkan bahwa orang yang memilih alternatif kendaraan pribadi setelah hadirnya transportasi online adalah orang yang sebelumnya menggunakan angkutan umum/bus dalam perjalanan menuju simpul transportasi, jika tidak tersedianya transportasi online orang akan beralih menggunakan kendaraan pribadi yang mengakibatkan meningkatnya pengguna kendaraan pribadi dan pengguna angkutan umum akan terus menurun dan fungsi angkutan umum sendiri akan hilang.

Dengan melihat hasil penelitian, bahwa yang paling rentan mengalami substitusi adalah angkutan umum, maka dari itu disarankan untuk meningkatkan kualitas angkutan umum di Kota Bandung untuk mengurangi substitusi angkutan umum yang beralih ke angkutan online, karena yang diharapkan adalah angkutan online bisa menggantikan ketergantungan kepada kendaraan pribadi namun tidak mengsubstitusi angkutan umum.

\section{UCAPAN TERIMA KASIH}

Data yang digunakan dalam penelitian ini dibiayai oleh Hibah Publikasi Internasional Institut Teknologi Nasional Bandung 2020. Para penulis berterimakasih kepada Andrean Maulana sebagai ketua tim peneliti dari hibah tersebut. Selain itu para penulis berterimakasih kepada pihak-pihak yang membantu pengumpulan data.

\section{DAFTAR PUSTAKA}

[1] M. Rizki, T. B. Joewono, P. F. Belgiawan, and M. Z. Irawan, "The travel behaviour of ride-sourcing users, and their perception of the usefulness of ride-sourcing based on the users' previous modes of transport: A case study in Bandung City, Indonesia," IATSS Research, Dec. 2020, doi: 10.1016/j.iatssr.2020.11.005.

[2] A. Tirachini, "Ride-hailing, travel behaviour and sustainable mobility: an international review," Transportation, Nov. 2019, doi: 10.1007/s11116-019-10070-2.

[3] F. Nangoy and C. Silviana, "Indonesian taxi drivers to rally for ban on online taxi apps," Reuters, Mar. 21, 2016. Accessed: Feb. 18, 2021. [Online]. Available: https://www.reuters.com/article/indonesia-taxis-idUSL3N16T28C

[4] R. R. Clewlow and G. S. Mishra, "Disruptive Transportation: The Adoption, Utilization, and Impacts of Ride-Hailing in the United States," Oct. 2017, Accessed: Jun. 12, 2020. [Online]. Available: https://escholarship.org/uc/item/82w2z91j

[5] M. Z. Irawan, P. F. Belgiawan, A. K. M. Tarigan, and F. Wijanarko, "To compete or not compete: exploring the relationships between motorcycle-based ride-sourcing, motorcycle taxis, and public transport in the Jakarta metropolitan area," Transportation, Jun. 2019, doi: 10.1007/s11116-019-10019-5.

[6] A. Y. Suatmadi, F. Creutzig, and I. M. Otto, "On-demand motorcycle taxis improve mobility, not sustainability," Case Studies on Transport Policy, vol. 7, no. 2, pp. 218-229, Jun. 2019, doi: 10.1016/j.cstp.2019.04.005.

[7] Warta Ekonomi, "Angkutan Online Marak, Pendapatan Damri Turun 2\%," Warta Ekonomi, Nov. 10, 2016. https://www.wartaekonomi.co.id/read119732/angkutan-onlinemarak-pendapatan-damri-turun-2 (accessed Jul. 18, 2020).

[8] Warta Ekonomi, "Taksi Online Dilarang Ambil Penumpang di Terminal Depok," Warta Ekonomi, Jun. 14, 2019. https://www.wartaekonomi.co.id/read231893/taksi-online-dilarangambil-penumpang-di-terminal-depok (accessed Jul. 18, 2020). 
[9] D. N. Anderson, "'Not just a taxi'? For-profit ridesharing, driver strategies, and VMT," Transportation, vol. 41, no. 5, pp. 1099-1117, Sep. 2014, doi: 10.1007/s11116-014-9531-8.

[10] M. Rizki, T. B. Joewono, and J. Syahputri, "EKSPLORASI MODA ASAL PENGGUNA TRANSPORTASI ONLINE DI KOTA BANDUNG," Jurnal Transportasi, vol. 20, no. 1, Art. no. 1, 2020, doi: 10.26593/jtrans.v20i1.3849.1-10.

[11] M. Young and S. Farber, "The who, why, and when of Uber and other ride-hailing trips: An examination of a large sample household travel survey," Transportation Research Part A: Policy and Practice, vol. 119, pp. 383-392, Jan. 2019, doi: 10.1016/j.tra.2018.11.018.

[12] F. F. Dias, P. S. Lavieri, V. M. Garikapati, S. Astroza, R. M. Pendyala, and C. R. Bhat, "A behavioral choice model of the use of car-sharing and ride-sourcing services," Transportation, vol. 44, no. 6, pp. 1307-1323, Nov. 2017, doi: 10.1007/s11116-017-9797-8. [13] M. Rizki, T. B. Joewono, P. F. Belgiawan, and D. Prasetyanto, "Exploring the RideHailing Drivers' Characteristics and Their Order Rejection Behavior in Bandung City," in ICCOEE2020, Singapore, 2021, pp. 861-869. doi: 10.1007/978-981-33-6311-3_98.

[14] M. Z. Irawan, P. F. Belgiawan, T. B. Joewono, and N. I. M. Simanjuntak, "Do motorcycle-based ride-hailing apps threaten bus ridership? A hybrid choice modeling approach with latent variables," Public Transp, vol. 12, no. 1, pp. 207-231, Mar. 2020, doi: 10.1007/s12469-019-00217-w.

[15] L. Rayle, D. Dai, N. Chan, R. Cervero, and S. Shaheen, "Just a better taxi? A surveybased comparison of taxis, transit, and ridesourcing services in San Francisco," Transport Policy, vol. 45, pp. 168-178, Jan. 2016, doi: 10.1016/j.tranpol.2015.10.004.

[16] J. F. Hair, W. C. Black, B. J. Babin, and R. E. Anderson, Multivariate Data Analysis. Harlow, Essex: Pearson, 2010. Accessed: Jul. 21, 2020. [Online]. Available: https://www.pearson.com/uk/educators/higher-education-educators/program/HairMultivariate-Data-Analysis-Global-Edition-7th-Edition/PGM916641.html

[17] M. Z. Irawan, M. Rizki, T. B. Joewono, and P. F. Belgiawan, "Exploring the intention of out-of-home activities participation during new normal conditions in Indonesian cities," Transportation Research Interdisciplinary Perspectives, vol. 8, p. 100237, Nov. 2020, doi: 10.1016/j.trip.2020.100237. 